\title{
Analysis of Strategic Factors Affecting the Success of Small Enterprises in South Sulawesi
}

\author{
Fitriany ${ }^{1}$ and Zainal Abidin ${ }^{2}$ \\ ${ }^{1,2}$ Candidate Doctor of Economic, Hasanuddin University, Indonesia \\ ${ }^{2}$ Lecturer of University Muslim Maros, Indonesia
}

2Email: zainalabidin@umma.ac.id

\begin{abstract}
The purpose of the present study is to analyse the effect of managerial competence, information access on cost, benefit differentiation of small business products. This research is done in five district in South Sulawesi- Makassar, Maros, Bantaeng, Bulukumba and Tanah Toraja. The populations of this study are owners and managers of food and beverage business, wood and rattan furniture, convection and apparel. The sample was chosen purposively for 170 responders. Survey and questionnaire were used in data collection. Then the data were analysed descriptively and structural equation model with AMOS (Analysis of moment structural) program.

The results of the study show that the success of small-scale enterprises is directly influenced by strategic factors, namely managerial competence, information access, and product differentiation. The factors of negative cost advantage but significant influence the success of the business because customers prefer the uniqueness. If small entrepreneurs in South Sulawesi want to succeed, then it should pay attention to the factor of product differentiation superiority because the influence is big enough and significant to the success of small business. This identifies that small business products should be more unique in terms of more value than a cheaper price.

Keywords: Manager's Competence, Access to Information, Cost Advantage, Advantage of Deferment, Business Success.

JEL : M19

DOI : : 10.24002/kinerja.v22i2.1807

Received : 27-07-2018 Reviewed: 30-07-2018 Final Version: 26-08-2018
\end{abstract}




\section{INTRODUCTION}

Small and Medium Enterprises (SME) are important actors in the economy of a country or region. Its contribution to Grosas Domestic Product (GDP) is 56.7 percent and in non-oil exports by 15 percent, contributes about 99 percent in the number of business entities in Indonesia and has a share of 99.6 percent in employment. SMEs has less attention from the government so it needs training on SMEs, especially in the field of marketing (Nawawi, 2009).

The number of business actors in Indonesia's MSME (Micro Small and Medium Enterprises) industry is among the most among other countries, especially since 2014. The number of MSME in Indonesia continues to improve from 2015 to 2017 and will continue to grow (MSME data 2015, 2016, 2017). Data from the Ministry of Cooperatives and Small-Medium Enterprises stated that there are about 57.8 million actors of SMEs in Indonesia in 2014. In 2017 and the years forecasted, it is estimated that the number of MSME perpetrators will continue to grow. MSMEs have an important and strategic role in national economic development. In addition, MSMEs also play a role in distributing development outcomes.

All this time, MSME has contributed $57,60 \%$ Gross Domestic Product (PBD) and employment rate about $97 \%$ of all national work force (MSME Business Profile by LPPI and BI 2015). It is similar to Indonesian Chamber of Commerce cited that the contribution of the MSME sector to gross domestic product increased $57.84 \%$ to $60.34 \%$ in the last five years. Labor absorption in this sector also increased from $96.99 \%$ to $97.22 \%$ in the same period.

The contribution of SMEs in the economy includes: able to create employment due to labor-intensive, increasing regional economic growth, acting as complementary partners for large enterprises, as training for employers and young workers in developing business and interpersonal skills. SMEs are able to reduce the country's vulnerability to the financial crisis with its success and survival (Beal \& Abdullah, 2003).

Number of studies show that the small business sectors of manufacturing industry experienced growth in businesses that produce certain superior products. It is not only having high added value but also absorbing a number of workforce. In today's complex global economic development, the role of the small industry sector is being more important in the national economy. The essence and efficiency of the sector are larger and have a strategic position, because besides having a comparative advantage is also natural in the form of availability of abundant raw materials, but making the cost of production becomes cheaper and has a weak competitiveness in the face of medium and large entrepreneurs. The development of small-scale enterprises in South Sulawesi is as follows: 
Table 1. Number of Small-Medium Industry by Regency in South Sulawesi Province 2017

\begin{tabular}{r|l|l|l}
\hline No. & Ditrict & $\begin{array}{l}\text { Bussiness unit } \\
\text { (unit) }\end{array}$ & $\begin{array}{l}\text { Staff } \\
\text { (person) }\end{array}$ \\
\hline 1. & Kep. Selayar & 8.218 & 17.305 \\
2. & Bulukumba & 3.690 & 1.162 \\
3. & Bantaeng & 1.587 & 7.254 \\
4. & Jeneponto & 2.770 & 4.894 \\
5. & Takalar & 1.811 & 7.964 \\
6. & Gowa & 2.756 & 1.3736 \\
7. & Sinjai & 147 & 5.43 \\
8. & Maros & 2.305 & 1.4541 \\
9. & Pangkep & 2.194 & 1.0496 \\
10. & Barru & 1.545 & 5.363 \\
11. & Bone & 3.969 & 5.2338 \\
12. & Soppeng & 336 & 1.570 \\
13. & Wajo & 340 & 2.0985 \\
14. & Sidrap & 4.035 & 1.2997 \\
15. & Pinrang & 1.946 & 6.203 \\
16. & Enrekang & 3.583 & 1.2434 \\
17. & Luwu & 738 & 2.966 \\
18. & Tana Toraja & 716 & 2.555 \\
19. & Luwu Utara & 1.175 & 5.828 \\
20. & Luwu Timur & 566 & 3.550 \\
21. & Toraja Utara & 775 & 1.948 \\
22. & Makassar & 4.472 & 9.0467 \\
23. & Parepare & 1.142 & 4.156 \\
24. & Palopo & 543 & 2.650 \\
\hline Total & 51.278 & 314.405 \\
\hline
\end{tabular}

Table 2. Number of MSME (Micro Small and Medium Enterprises) in South Sulawesi Province in 2017

\begin{tabular}{|c|c|c|c|c|c|c|c|c|}
\hline \multirow{2}{*}{ No. } & \multirow{2}{*}{ District } & \multicolumn{2}{|c|}{ Micro Enterprise } & \multicolumn{2}{|c|}{ Small Enterprise } & \multicolumn{2}{|c|}{ Medium Enterprises } & \multirow{2}{*}{ Size } \\
\hline & & Total & Identified & Total & Identified & Total & Identified & \\
\hline 1. & Selayar & 14.537 & 9.647 & 797 & 1.154 & 32 & 72 & 7 \\
\hline 2. & Bulukumba & 41.490 & 121.448 & 3.137 & 13.784 & 136 & 1.947 & 84 \\
\hline 3. & Bantaeng & 21.749 & 1.374 & 1.306 & - & 30 & - & 10 \\
\hline 4. & Jeneponto & 35.155 & 7.859 & 3.350 & 397 & 58 & 14 & 16 \\
\hline 5. & Takalar & 32.786 & 9.568 & 4.334 & 140 & 68 & - & 29 \\
\hline
\end{tabular}




\begin{tabular}{|c|c|c|c|c|c|c|c|c|}
\hline \multirow{2}{*}{ No. } & \multirow{2}{*}{ District } & \multicolumn{2}{|c|}{ Micro Enterprise } & \multicolumn{2}{|c|}{ Small Enterprise } & \multicolumn{2}{|c|}{ Medium Enterprises } & \multirow[t]{2}{*}{ Size } \\
\hline & & Total & Identified & Total & Identified & Total & Identified & \\
\hline 6. & Gowa & 70.707 & 3.448 & 10.284 & 1.381 & 147 & 141 & 30 \\
\hline 7. & Sinjai & 22.645 & 5.065 & 2.016 & 3.456 & 48 & 1.152 & 15 \\
\hline 8. & Maros & 26.358 & 23.747 & 4.075 & 6.420 & 92 & 796 & 40 \\
\hline 9. & Pangkep & 28.910 & 26.832 & 3.365 & 3.674 & 77 & 247 & 31 \\
\hline 10. & Barru & 16.409 & 16.196 & 1.901 & 1.492 & 40 & 69 & 19 \\
\hline 11. & Bone & 80.213 & 1.835 & 7.009 & 335 & 105 & 52 & 56 \\
\hline 12. & Soppeng & 24.929 & 4.254 & 3.268 & 973 & 58 & 89 & 18 \\
\hline 13. & Wajo & 52.331 & 895 & 6.220 & 337 & 158 & 28 & 45 \\
\hline 14. & Sidrap & 25.518 & 11.487 & 3.098 & 2.517 & 61 & 248 & 17 \\
\hline 15. & Enrekang & 16.481 & 4.348 & 1.817 & 218 & 48 & 2 & 11 \\
\hline 16. & Luwu & 29.484 & 29.494 & 2.401 & 2.609 & 46 & 92 & 16 \\
\hline 17. & Tana Toraja & 13.524 & 2.059 & 1.382 & 381 & 45 & 44 & 24 \\
\hline 18. & Luwu Utara & 20.673 & 12.247 & 3.613 & 61 & 89 & 10 & 26 \\
\hline 19. & Luwu Timur & 17.490 & 6.059 & 2.414 & 3.992 & 99 & 8 & 30 \\
\hline 20. & Makassar & 134.795 & 4.441 & 35.731 & 7.250 & 1.447 & 989 & 670 \\
\hline 21. & Parepare & 12.828 & 7.849 & 2.565 & 1.081 & 96 & 97 & 37 \\
\hline 22. & Palopo & 11.099 & 2.220 & 2.838 & 1.334 & 104 & 64 & 47 \\
\hline 23. & Pinrang & 27.991 & 962 & 4.269 & 114 & 86 & 12 & 31 \\
\hline 24. & Toraja Utara & 18.979 & 1.831 & 3.467 & 591 & 15 & 194 & \\
\hline & Total & 797.081 & 315.165 & 114.656 & 53.691 & 3.185 & 6.367 & 1.309 \\
\hline
\end{tabular}

Source: Department of Cooperative and MSME of South Sulawesi

There are five main problems faced by small business in five areas. They are (1) Weak in design; (2) The low productivity caused by the quality of human resources and technology; (3) Frequent fluctuations in raw material supply, both of quality and price; (4). Low awareness of entrepreneurs about Intellectual Property Rights; and (5). The existence of new product market competition.

The phenomenon of low quality of human resources owned and unpreparedness of small businesses in mastering information technology led to low access to information to stakeholders (Suryana, 1999) (Cravens, 2003). Manager's competence is clearly expressed through a competency profile that includes; Knowledge, skills, abilities, attitudes directly contribute to the effectiveness of performance (Nankervis and Brocklesby (1995: 70), while access to information refers to Cravens (2003) income that explains that, three information that the company needs to know: customer information, competitions information and other market information, as well as media and information sources that must be mastered, so that the company or manager can obtain information fast and accurate, while the basic types of excellence, namely cost advantage and differentiation (Porter 1994) (Philip Kotler, 1994: 408). 
Therefore, this research aims to identify the influence of managerial competence and information access to the competitive advantage of the company in the case of cost advantage and differentiation, and how the implication to the success of small business.

\section{LITERATURE REVIEW}

This study discusses small-business management theories (strategic management) which include understanding small businesses, competencies, access to information and competitive advantages (cost advantages and differentiation advantages), and business success, as well as previous research.

\subsection{Small Enterprises}

Ziang (2002), Horowitz and Demerilie (1978) stated six characteristics of small businesses. These characteristics are mentioned below:

a. Very dependent on the owner of the company (always manager)

b. The business is easy to set up

c. Operate with capital collected by the manager

d. Simple management structure

e. Full of innovation

f. Easy to be influenced by the environment

Small enterprises have a very important role for the Indonesian economy because the numbers of enterprises and easily spread in rural areas (Tezler, 1995). On the other hand, the classification of small industries continues according to the Ministry of Industry (1992) based on the criteria are based on the Commodity Sector, the type of product and investment as well as Legal Status.

It's sufficient the swiftest attempt to study SMEs to understand that there is no specific definition of them that may be taken as a reference by all economies, statistical agencies or researchers of economy. Despite the lack of universality of the definition and the lack of alignment in the criteria, the importance of SMEs definition is inalienable. The definition of small and medium enterprises is important and useful: in the preparation of statistics and the monitoring of the health of the sector over time; in benchmarking against other economies and between regions within an economy; in providing arbitrary thresholds for imposition of tax or other regulations; in determining eligibility for particular forms of public support (UNIDO OECD: 2004). Small and medium enterprises are named by adjectives indicating size, thus economists tend to divide them into classes according to some quantitative measurable indicators. The most common criterion to distinguish between large and small businesses is the number of employees (Hatten, 2011). One of the first attempts to provide a definition of SMEs is that of the Bolton Report 1971 (Carter and Jones-Evans, 2006). 


\subsection{Competence}

The concept of competence or competency ('competence' generally refers to functional areas and 'competency' to behavioral areas but usage is inconsistent, as shown below) dominated the management strategy literature of the 1990s, which emphasized 'core competence' as a key organizational resource that could be exploited to gain competitive advantage (e.g. Campbell and Sommers Luchs, 1997; Mitrani, et al., 1992; Nadler and Tushman, 1999). Hamel and Prahalad (1994) defined core competence as 'the collective learning in the organizations, especially how to co-ordinate diverse production skills and integrate multiple streams of technologies' (Prahalad and Hamel, 1990: 82). From the perspective of a resourcebased theory of the firm, sustained competitive advantage is seen as deriving from a firm's internal resources if these can add value, are unique or rare, are difficult for competitors to imitate and are non-substitutable (Cappelli and Crocker-Hefter, 1996; Ellestro"m, 1992; Foss and Knudsen, 1996). The virtue of the core competence approach is that it 'recognizes the complex interaction of people, skills and technologies that drives firm performance and addresses the importance of learning and path dependency in its evolution' (Scarborough, 1998).

Spencer-spencer (1993) and William (1995) mentioned that individual competency is described as a basic characteristic of a worker who uses the deepest part of his personality and can influence behavior when he faces work and ultimately influences the ability to produce work performance. Hay-McBer (McClelland, Boyatzis, Spencer \& Spencer) proposed five types of competencies. These are motives, traits, self-concept, knowledge and skill. Furthermore, a study in several large industries in America by Rowe (1995) discovered that competence divided into three groups that can be a general identification of the competence of an employee which are eligibility, suitability and ability. Hence, those studies showed that the competence of the manager has a strategic role both facing the competition and achieving success.

There is such confusion and debate concerning the concept of competence that it is impossible to identify or impute a coherent theory or to arrive at a definition capable of accommodating and reconciling all the different ways that the term is used (Ellestrm, 1997; Robotham and Jubb, 1996). This terminological confusion often reflects conflation of distinct concepts and inconsistent usage of terms as much as different cultural traditions. However, some differences are attributable to different epistemological assumptions (Pate, Martin and Robertson, 2003) and the rationale for the use of competence often determines the definition (Hoffman, 1999). As Norris (1991: 332) argued, tacit understandings of the word [competence] have been overtaken by the need to define precisely and [to] operationalize concepts, the practical has become shrouded in theoretical confusion and the apparently simple has become profoundly complicated. Describing competence as a fuzzy concept, Boon and van der Klink (2002:6) nonetheless acknowledge it as a useful term, bridging the gap between education and job requirements. 


\subsection{Access to Information}

Jay Gasperrsz (1996) stated that the greater the uncertainty the greater the amount of information must process between decision making during the execution of tasks in order to achieve a certain level of achievement. Cravens (2003) marketing managers need to be aware of changes in information technology and are always vigilant in paying attention to increasing competitive advantage in terms of information.

\subsection{Competitive Advantage}

Competition is at the core of the success or failure of firms. Competition determines the appropriateness of a firm's activities that can contribute to its performance, such as innovations, a cohesive culture, or good implementation. Competitive strategy is the search for a favorable competitive position in an industry, the fundamental arena in which competition occurs. Competitive strategy aims to establish a profitable and sustainable position against the forces that determine industry competition. Two central questions underlie the choice of competitive strategy. The first is the attractiveness of industries for long-term profitability and the factors that determine it. Not all industries offer equal opportunities for sustained profitability, and the inherent profitability of its industry is one essential ingredient in determining the profitability of a firm. The second central question in competitive strategy is the determinants of relative competitive position within an industry. In most industries, some firms are much more profitable than others, regardless of what the average profitability of the industry may be. Neither question is sufficient by itself to guide the choice of competitive strategy. A firm in a very attractive industry may still not earn attractive profits if it has 'chosen a poor competitive position. Conversely, a firm in an excellent competitive position may be in such a poor industry that it is not very profitable, and further efforts to enhance its position will be of little benefit. Both questions are dynamic; industry attractiveness and competitive position change. Industries become more or less attractive over time, and competitive position reflects an unending battle among competitors. Even long periods of stability can be abruptly ended by competitive moves (Porter:1985).

Competitive advantage basically develops from the value that a company can create for its buyers that exceeds the company's costs in creating it (Porter, 1993). Besides, Dranove and Shanley (2000) point to economic profitability as an indicator of competitive advantage.

\section{a. Cost advantages}

In the purpose to cost analysis, the separation of generic chains into each value activity should reflect three interrelated principles, namely: 1) the size and growth of costs represented by activities, 2). Activity cost behavior, 3) differences in competitors in carrying out activities (Porter, 1994). 


\section{b. Business Success}

Sweeezy (1990) and Cusson (1982) said the company's performance can be viewed from two aspects-performance as a process and performance as a result. In order to to deal with increasingly complex competition and internal crises, small entreprises can use resource-based strategy theory (Mohoney and Pandian, 1992).

\section{METHODOLOGY}

This research is done in five district in South Sulawesi- Makassar, Maros, Bantaeng, Bulukumba and Tanah Toraja. The population in this study is a sampling population that is all small industrial processing companies in these areas. While the target population is a processing industry company that has a Industry register mark and produces food and beverages, wood and rattan furniture, convection and apparel, metal and silver. The sample size of at least 170 business units is allocated in an average to sub group of industry subtypes.

The populations of this study are owners and managers of food and beverage business, wood and rattan furniture, convection and apparel. The sample was chosen purposively for 170 responders. Survey and questionnaire were used in data collection.

The variables used are classified in two parts, exogenous and endogenous variables. The exogenous variables are included competence and access to information while endogenous variables are cost advantages, superior differentiation and business success. Then the data were analyzed descriptively and structural equation model with AMOS (Analysis of moment structural) program. This research was conducted to test the hypothesis and analyze and explain the causal relationship (causal relationship) between research variables.

Thus the research design is descriptive analysis research (Nazir, 1988, 1999, and Gee, 1950). Descriptive research is a study to find facts through proper interpretation, and can be useful as a problem solution, while analytical research is research aimed at testing hypotheses and conducting a deeper interpretation of causal relationships between research variables (Nazir, 1988), 1999), done by designing cross-sectional data and through testing using statistical tests. Data analysis method in this research is done by using analysis technique: 1). Descriptive analysis of each research variable, 2). Statistical Analysis with SEM (Structural Equation Modeling) model with AMOS (Analysis of Moment Structural) Version 07 and SPSS version 16. 


\section{RESULT AND DISCUSSION}

To see independent variables influence each dependent variable, authors describe the model. Analysis model in this study is showed on this figure below:

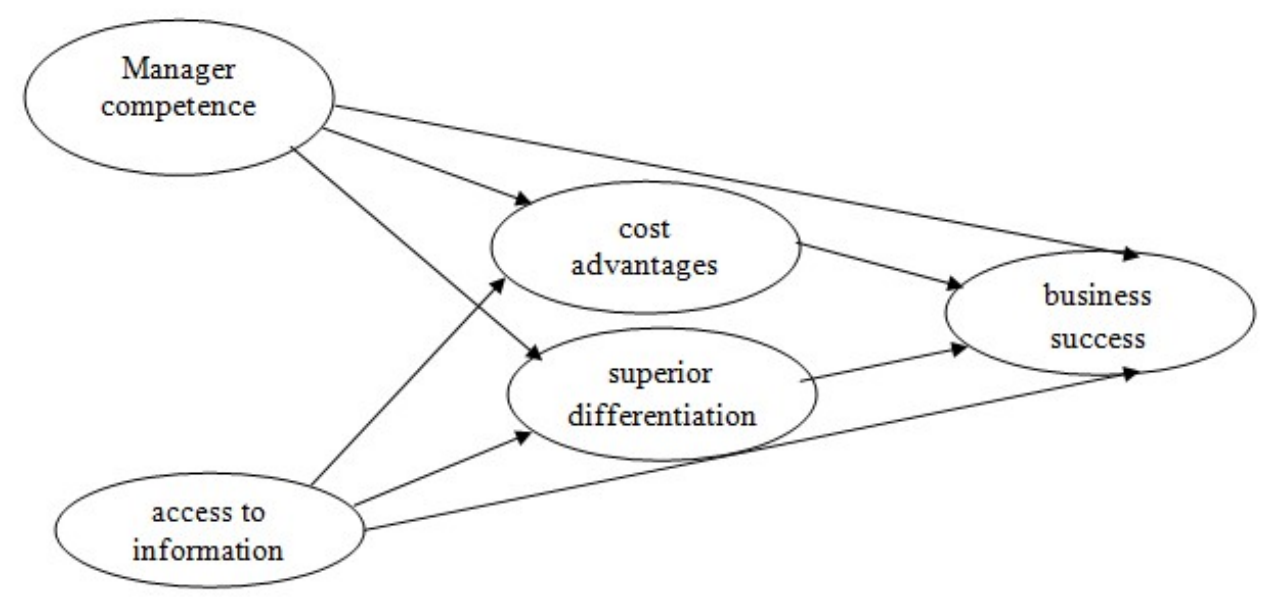

Figure 1. Research Model

The dominant indicators that make up the research variables (Measurement Model) describe three main things measurement model that is: 1) the value of Loading Factor or regression weight with the symbol lambda (Ferdinand <2002: 79). 2) significant levels on each construct. 3) construct reliability. However, in this measurement model, the most importantly is the significant level (must be less than $5 \%$ or below 0.05$)$ and the value of construct reliability $\left(p^{n}\right)>0.70$. The variable is said to be valid unidimensional if it has the value of Goodness of Fit Index (GF)> 0.90. The value of Loading Factor of this study mentioned below:

a. Manager's Competency Loading Factor

All indicators show a significant sign below $5 \%$ for all indicators of knowledge $(\Lambda 1,000)$, skill $(\wedge 0.988)$, ability $(\wedge 0.639)$, attitude and motivation ( 1 1.739)

b. Loading Factor Access Information

All indicators can measure significantly below $5 \%$ for all for all indicators. The customer information indicator $(\wedge 1.013)$ as the dominant indicator forms the access information variable and subsequently the media and information sources $(\Lambda 1,000)$, competitor information $(\Lambda 1.598)$ and market information $(\Lambda 0.360)$.

\section{c. Loading Factor Cost Advantage}

Cost advantage showed a significant result for all indicators, below $5 \%$. The dominant variable cost indicator forms the cost advantage variable $(\Lambda 1.277)$ 
and the competitor cost $(\Lambda 1.050)$, efficient cost $(\Lambda 1,000)$, marginal cost $(\Lambda$ $0.0882)$ and low cost orientation ( $\Lambda$ 0.818).

\section{d. Loading Factor Excellence Differentiation}

It experienced significant result, below $5 \%$. Product quality indicator $(\wedge$ $1.116)$ is dominant in forming variables of differentiation superiority, then payment method $(\Lambda 1.549)$, timeliness $(\Lambda 0.617)$, service quality $(\Lambda 0.551)$ and product type $(\Lambda 1.000)$.

\section{e. Loading Factor success of the business.}

Four indicators can measure significantly against constructs or business success variables. This is stated with a sign significantly below $5 \%$ for all indicators. But the indicator of the number of labor is not significant $(\Lambda$ 0.060).

In addition, based on construct reliability value (Test Reliability Construct), the value of the competence of the competence of the manager, access to information, cost advantage, differentiation advantages, and the success of each business amounted to 0.844 . This means that all variables or constructs in this study are reliable because the construct has a construct reliability value of $d$ of 0.70 .

Furthermore the result of this study showed that manager competence is very necessary for small businesses and is a prerequisite for the formation of corporate power to support competitive advantage, especially cost advantage in the company. While, competitive advantage is a prerequisite for the company to be able to compete in the era of free trade as an influence of globalization in the economic field. These results show that some small-scale companies have high differentiation advantages in the form of product design, product quality and service, but have low cost advantages, resulting in low competitive advantage. The success of business and competitive advantage in small industry is influenced by information access and managerial competence (Cravens, 2003), (Besanko-Dranove-Shanley (D_B_S), conception (Spencer and Spencer, 1993), (De Fillipi and Arthur, 1994) (David W. Cravens, 2003) (Michael W. Cravens, 1997), Michael Porter (1994) (Michael A Kitt, 1999), (Sweezy, 1990), (Cusson, 1982).) The results found that most large enterprise management small have competence in managing business.

On the other hand, access to information owned by corporate managers in the five cities is still limited or low. (Gibson, 1996), (Cravens, 2003), (Porter, 1994) suggests that corporate managers need to be aware of changes in information technology and are always vigilant in regard to competitive advantage in information. 


\section{CONCLUSION}

This study concludes that some facts that the better the competence of the manager-the owner of the small business, the easier it will be to manage the business especially in the company's cost control. Competence of manager has a strategic role in the face of competition, especially the advantages of product differentiation in the business. The better access to information made, will make it easier for companies to determine the cost advantage. Access to good information can create competitive advantage and superior value for consumers. Most small enterprise does not yet have an appropriate cost advantage, because the customer prefers the uniqueness of the superior value rather than the cheaper price. The better and higher the superiority of product differentiation, then the chances of success of small industry is getting bigger. The success of small industry business is determined by manager competency factor. The better access the information is made, the success of the small industry will increase.

On the other hand, it states some suggestions or recommendations. In developing small business, business managers need to pay attention to the company's circumstances including competence and access to information and competitive advantage by conducting education and training, searching and gathering information as well as developing information facilities. To increase competitive advantage both cost advantage and product differentiation superiority managers must have competence and control information. In addition, for related parties, both government, universities, associations, cooperatives and medium / large companies can conduct guidance and training for craftsmen in both production and managerial fields.

\section{ACKNOWLEGDMENT}

Authors would like to thank Indonesia Endowment Fund for Education (LPDP) for financial support. 


\section{REFERENCES}

Arsyad, L, 1996, Ekonomi Manajerial, Edisi Tiga, BPFE UGM.

Ball, Ben, 1997, Career Management Competences-Individual Perspective, Career Development International, 2/2, p. 74-79.

Beal, T \& Abdullah, M.A, 2003, The Strategic Contributions Of Small and Medium Enterprises To The Economics Of Japan And Malaysia, Some Competitive Lessons For Malaysian SMEs, Paper Presented to The Seventh International Conference Global Business and Economic Development Strategic For Sustainable Business Responses to Regional Demand, and Global Opportunity, Bangkok Thailand. p. 56-69.

Broclesby, J, 1995, Using Soft System Methodology to Identify Competence Requirement in HRM, International Journal of Manpower, Vol. 16 No. 5/6 p. $70-80$.

Cravens W. D \& Nigel F. F, 2003, Strategic Marketing, Seventh Edition, McGraw Hill Irwin, North America.

Gibson J. L, Ivancevich D, 1997, Organisasi: Perilaku, Struktur, dan Proses, translated by Nunuk Adiami Binarupa Aksara, Jakarta.

Gilmore, A \& David C, 1996, Management Competences for Services Marketing, The Journal of Services Marketing Vol. 10 No. 3 p. 39-57.

Hannon, P.D, Dean P, Sue, M, 2000, Transactional learning Relationship: Developing management Competencies for Effective Small Firm Stakeholder Interactions, Education \& Training Vol. 42 No. 4/5 p. 237 - 245.

Hamel \& Gary and Prahalad, C.K, 1990, The Core Competence of the Corporation, Harvard Business Review, Journal (May-June) 1990 p. 79-91.

Kotler, P, 1994, Economic Managerial, Marketing Management Analysis, Planning, Implementation and Control, Prentice Hall Inc. London.

Kotler, P, 2010. Marketing Management Analysis, Planning, Implementation, and Control, 12th Ed. Englewood Cliff, NJ. New Jersey: Prentice-Hall, Inc.

Mahoney, J. T, Jr, Pandian 1992, The Resource based View within Conversation of Strategic Management, Journal.

Munro, A \& Brenden, A, 1994, Competences; Dialogue without a Plot? Providing Context through Business Diagnostics, Executive Development, Vol. 7 No.6 p. $12-15$.

Porter, M. E, 1994, Keunggulan Bersaing, Menciptakan dan Mempertahankan Kinerja Unggul, Terjemahan Tim Binarupa Aksara, Erlangga, Jakarta. 
Rowe, C, 1995, Clarifying The Use of Competence and Competency model in Recruitment, Assessment and Staff Development, Industrial and Commercial Training, Vol 27, No 11 p. 12-17.

Sekaran, U, Roger, B, 2010, Research Methods For Business A Skill Building Approach, A John Wiley and Sons Ltd Publication.

Spencer, L.M, D.C, McLelland, and S. M Spencer, 1993, Competence of Work, John Willey and Sons Inc, New York.

Salvator, D, 2001, Managerial Economic in Global Economy, Harcourt College Publisher.

Soeharsono, S. H, 1993, Faktor sumber Daya Manusia, Teknologi dalam Upaya meningkatkan Daya Saing Industri Menengah Kecil (Pendekatan Makro Ekonomi), Majalah dan Usahawan Indonesia No. 6 Th XXII.

\section{EXTERNAL SOURCE}

Biro Pusat Statistik, 2017, Statistik Indonesia

LPPI dan BI, 2015, Profil Bisnis UMKM. 